Article

\title{
Resident Support for Tourism Development in Rural Midwestern (USA) Communities: Perceived Tourism Impacts and Community Quality of Life Perspective
}

\author{
Chia-Pin $\mathrm{Yu}^{1, *(\mathbb{D})}$, Shu Tian Cole ${ }^{2}$ and Charles Chancellor ${ }^{3}$ \\ 1 School of Forestry and Resource Conservation, National Taiwan University, Taipei 10617, Taiwan \\ 2 Department of Recreation, Park, and Tourism Studies, Indiana University, Bloomington, IN 47405, USA; \\ colest@indiana.edu \\ 3 Department of Recreation, Park, and Tourism Management, Clemson University, Clemson, SC 29634, USA; \\ hchance@clemson.edu \\ * Correspondence: simonyu@ntu.edu.tw; Tel.: +886-2-3366-4618
}

Received: 31 January 2018; Accepted: 10 March 2018; Published: 13 March 2018

\begin{abstract}
Local residents play an important role in the process of sustainable development in tourism. Resident support for tourism development contributes to the health of tourism industry and successful community development. Therefore, it is in the best interest of local residents, the tourism industry, and tourists, that residents have a positive outlook on and positive experiences with tourism development. In order to understand resident support for tourism development from tourism impacts and community quality of life perspective within the rural communities of Orange County, Indiana, USA, this study has examined a proposed structural model which incorporates eight latent variables: (a) six types of positive and negative tourism impacts serve as exogenous latent variables; (b) tourism-related community quality of life (TCQOL) is proposed as the mediating variable; and (c) resident support for tourism development is the ultimate dependent variable. The results show that both sociocultural and environmental benefits contribute to the host community's living experience. Economic and sociocultural benefits, negative sociocultural and environmental impacts, and TCQOL influence resident support for tourism development. This study identified specific tourism impacts that affect TCQOL and resident support for local tourism development. This study affirms that community quality of life (QOL) serves an effective predictor of support for tourism development.
\end{abstract}

Keywords: sustainable tourism development; rural communities; tourism support; perceived tourism impacts; tourism-related community quality of life (TCQOL)

\section{Introduction}

Successful tourism development involves balancing relationships among tourists, residents, places, and the organizations and businesses that provide tourism services [1]. Tourism development exerts a myriad of effects that change the host community's living experience. Local community participation and support for tourism is necessary for sustainable tourism development [2]. Residents of host communities are considered an integral part of the "tourism experience". Murphy [3] suggested that goodwill and cooperation of the host community contribute to selling destination experiences and identified the need of community participation to tourism development and marketing. Residents' receptiveness and friendliness toward tourists affect directly with a positive experience, which influences the likelihood of tourists returning to the destination and the delivery of word-of-mouth recommendations [4]. Therefore, understanding resident attitudes toward tourism development enables tourism and government leaders to design favorable strategies for community development, which in turn leads to higher support from host communities [5]. Tourism proponents consider tourism 
essential to the prosperity of local communities, through raising resident standard of living, which results in improving resident quality of life (QOL) [4]. The hospitality of local residents of a tourism destination affects the health of the tourism industry, and tourism destinations should be developed according to their needs [6].

Resident attitudes toward tourism development studies have considered that perceived tourism impacts affect support for tourism and influence resident satisfaction with community QOL. Positive tourism impacts positively change the lives of residents and vice versa [7]. Resident community living experience resulting from tourism may be a useful concept for evaluating support for tourism development [8]. Thus, residents who perceive higher tourism-related community quality of life (TCQOL) tend to support tourism more than those who perceive lower TCQOL. Hence, TCQOL may be a crucial concept in research on resident attitudes and a considerable factor for predicting resident support for tourism. In resident attitudes literature, researchers examined individual and aggregate effects of positive and negative tourism impacts on community QOL [8-10]. Kim, Uysal and Sirgy [11] further examined residents' perceptions of various tourism impacts that influence sense of wellbeing in several life domains and consequently affect life satisfaction in general. Previous works were acknowledged, however, the relationships among perceived tourism impacts, community QOL and tourism support have not been examined holistically in tourism literature. Additionally, while several valuable works have been recognized for exploring resident QOL [8,10], these projects fail to separate the residents' perceived community QOL resulting from tourism in the context of community development. For example, if residents perceive increased traffic congestion, is it due to tourism development or other development in a community? In other words, the effects on resident QOL may be the result of tourism and/or other modernization forces. If study on resident QOL related to tourism development includes the effects of other developments on QOL, the effects of tourism are not accurately measured. In this context, there is a research gap in incorporating an appropriate QOL measuring approach to comprehensively examine the relationships between tourism impacts, TCQOL and support for tourism development. To this end, authors modified Andereck and Nyaupane's [12] measuring approach of QOL in the context of tourism development that incorporates scales of importance, satisfaction, and perception of tourism effect. In this study, TCQOL indicators were therefore measured by importance, satisfaction, and perceived tourism effects that reflect the subjective nature of experiences and measure residents' living experiences resulting from tourism. In order to examine these relationships, the authors developed and tested a proposed model that illustrates the relationships between six types of tourism impacts, TCQOL, and residents' support for tourism development. The analytical framework is useful in understanding factors that influence residents' community QOL and their support for tourism their community. From a theoretical perspective, this study adds to existing social exchange theory (SET) by introducing community QOL factor to explain its mediation role between tourism impacts and resident support for tourism development. For managerial implications, this approach helps tourism leaders identify important factors that contribute to community quality of life and resident support for tourism.

\section{Literature Review}

\subsection{Community Quality of Life and Tourism Impacts}

QOL in the context of tourism development has become an emerging topic that has been broadly discussed [13]. The QOL studies have several levels, from individual, family, community, and state, as well as from subjective and objective perspectives [14,15]. The use of objective indicators such as educational assets, economic indices, health and recreation facilities were reported in community QOL studies [16,17]. There are various QOL definitions and models. Diener [18] argued subjective well-being is "how and why people experience their lives in positive ways, including both cognitive judgments and affective reactions". Veenhoven [19] highlighted happiness is "the degree to which an individual judges the overall quality of his life favorably". Philips [20] stated that happiness, 
life satisfaction, and subject well-being share a similar concept of quality of life. Sirgy and his colleagues [15] indicated individuals' QOL is their life satisfaction. Based on the bottom-up spillover theory $[18,21,22]$, Sirgy and his colleagues [15] suggested that the individual's global life satisfaction is a combination of other satisfaction domains. The bottom-up theory concludes that overall life satisfaction is the sum of many small satisfactions. Subjective quality of life can refer to happiness, satisfaction, and well-being and reflect both cognition and affection. Considering community resources cannot represent community QOL solely [23] and individuals may have different perceptions and experiences even if residing within the same community. Given the subjective nature of living experiences, scholars suggest that measures of residents' satisfaction of community life may better reflect their actual community life [15]. QOL studies at the community level have contributed to community development [15,24]. Community QOL studies aim to understand wellbeing, feelings, and perceptions of local residents, which are typically assessed the satisfaction. In the QOL literature, several dimensions such as satisfaction with local government services (e.g., infrastructure, education, and emergence), satisfaction with local business services (e.g., banking and entertainment), satisfaction with nonprofit services, and satisfaction with community conditions and specific issues of satisfaction within a community (e.g., satisfaction with tourism development) $[15,24]$. Satisfaction with community conditions includes resident perceptions of various physical (safety, traffic conditions), social (entertainment/recreation activities), and economic (employment opportunities, tax revenues) qualities in the community. Community services satisfaction includes resident perceptions of the various government, business, and nonprofit services that are potentially influenced by tourism development [25]. Positive and negative tourism impacts consequently influence community conditions and services [26-33].

Host communities experience three categories of benefits and costs in the progress tourism development: (a) economic, such as additional investments, infrastructure, tax, and inflation of goods and services; (b) sociocultural, such as improvement of cultural facilities, and promotion of cultural change; and (c) environmental, such as congestion, and pollutions [7,26,32,34-39]. Notably, resident perceptions of tourism are not homogeneous, and residents may consider tourism to have both positive and negative impacts $[2,40,41]$. These tourism impacts dynamically may change resident perceived community QOL, especially smaller cities where the impacts are more noticeable. Resident community QOL may be improved if the attractions also benefit residents [12].

In summary, residents recognize that tourism development causes positive and/or negative impacts and not surprisingly these positive and negative impacts change residents' QOL. Host communities may perceive improved resident QOL through the shared tourism products to both tourists and residents [37,42]. Additionally, through positive consequences such as job creation and increased tax revenues that result in higher purchasing power and services to residents can also improve resident QOL $[31,38,43-45]$. This is logically true for the negative case, as negative tourism impacts such as crowding, pollutions, and increased cost of living are detrimental to resident QOL $[26,29,37,42,46]$. Tourism development positively and negatively contributes to the well-being of communities in tourism destinations [11,47]. Researchers [28,31,48] have noted that a systematic analysis of tourism impacts, which includes positive-negative economic, sociocultural, and environmental perspectives, help tourism leaders identify concerns which should lead to better policies and actions that aid local residents.

\subsection{Resident Support for Tourism, Tourism Impacts, and TCQOL}

Resident support for tourism is measured by attitudes, including support for current, additional, and specific tourism development projects $[49,50]$. Numerous studies have reported that resident-perceived positive and negative tourism impacts predict the level of support for tourism [8,37,50-57]. From a theoretical perspective, social exchange theory (SET) which highlights that individuals engage in an exchange if the perceived benefits outweigh the costs supports the relationship [58]. Applying SET to a resident attitude study revealed that residents who benefit from tourism tend to have positive perceptions of tourism and therefore support tourism 
development, whereas those who do not benefit to their desired degree tend to have negative attitudes toward tourism and may oppose current or future tourism development [59]. In this sense, it can be postulated that residents perceiving higher community QOL are likely to support tourism and vice versa. Andereck and Nyaupane [12] addressed the relationship between QOL perceptions and support for tourism. Ko and Stewart [8] observed that positive and negative tourism impacts influence the overall community satisfaction of residents. By following Ko and Stewart, Vargas-Sanchez et al. [10] confirmed that community satisfaction was related to perceived positive tourism impacts in Minas de Riotinto, Spain. Nunkoo and Ramkissoon [60-62] considered satisfaction with community conditions and services as antecedents that predict resident support for tourism development. Therefore, resident community QOL can serve as a useful concept for evaluating resident support for tourism development [8]. These empirical studies have concluded that the level of tourism impacts and perceptions of living experiences in the host community influence resident support for tourism.

The purpose of this study was to investigate resident perceptions of community QOL resulting from tourism on the basis of their satisfaction with community conditions and services, namely, TCQOL. This study comprehensively examined the role of TCQOL in the relationships between antecedents (perceived tourism impacts) and consequences (resident support for tourism development). Specifically, this study strove to answer the following research questions:

(a) Do resident perceived tourism impacts influence TCQOL?

(b) Can resident perceptions of tourism impacts predict support for tourism development?

(c) Can TCQOL predict resident support for tourism development?

The proposed model with hypotheses are shown in Figure 1, followed by the specific sub hypotheses.

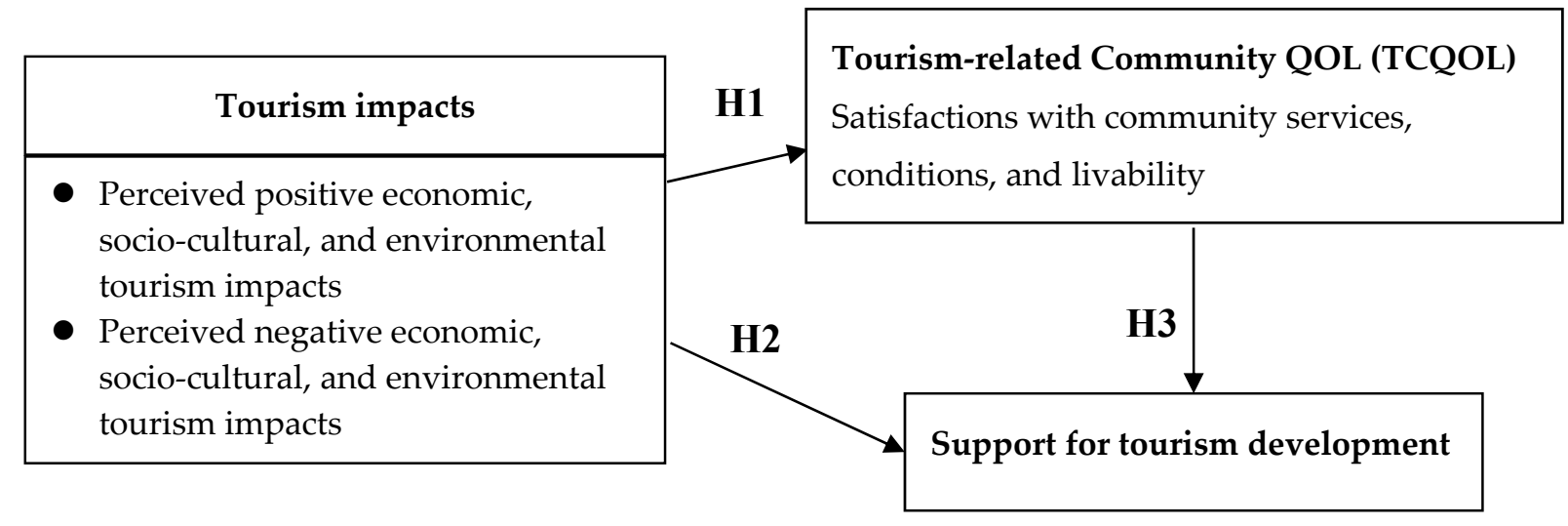

Figure 1. Proposed model and hypotheses in this study.

Six tourism impacts influence resident community QOL; however, the patterns of tourism impacts contributing to resident community QOL may vary from place to place. Thus, the present study extensively explored which tourism impacts influence resident community QOL. The following hypotheses are proposed according to the prior discussion:

Hypothesis 1: The resident perceptions of tourism impacts in a particular dimension affect TCQOL.

Hypothesis 1a: Resident-perceived positive economic impacts positively affect TCQOL.

Hypothesis 1b: Resident-perceived negative economic impacts negatively affect TCQOL.

Hypothesis 1c: Resident-perceived positive sociocultural impacts positively affect TCQOL. 
Hypothesis 1d: Resident-perceived negative sociocultural impacts negatively affect TCQOL.

Hypothesis 1e: Resident-perceived positive environmental impacts positively affect TCQOL.

Hypothesis 1f: Resident-perceived negative environmental impacts negatively affect TCQOL.

The current study comprehensively examined the effects of tourism impacts and TCQOL on support for tourism development. The following hypotheses are proposed:

Hypothesis 2: Residents' perceived tourism impacts in a particular dimension influence their support for tourism development.

Hypothesis 2a: Resident-perceived positive economic impacts positively influence support for tourism development.

Hypothesis 2b: Resident-perceived negative economic impacts negatively influence support for tourism development.

Hypothesis 2c: Resident-perceived positive sociocultural impacts positively influence support for tourism development.

Hypothesis 2d: Resident-perceived negative sociocultural impacts negatively influence support for tourism development.

Hypothesis 2e: Resident-perceived positive environmental impacts positively influence support for tourism development.

Hypothesis 2f: Resident-perceived negative environmental impacts negatively influence support for tourism development.

Hypothesis 3: Residents' perceived TCQOL affects their support for tourism development.

\section{Methods}

\subsection{Study Site}

Orange County is a rural area located in South Central Indiana and consisted of 7872 households with a total population of 19,802 as of 2010 [63,64]. Orange County was not affluent and agriculture and wood manufacturing were the primary industries [64]. The annual average personal income of Orange County was USD 29,042 in 2009, which ranked 73rd in income out of 92 counties [64]. Tourism is considered a re-emerging economic engine to stimulate local economy. In addition to traditional attractions, several new tourist attractions and amenities began opening in fall 2006, including a refurbished upscale resort, lodgings, a casino, and a water park. With new tourism investment, the average wage for the accommodations and food service sector ranks first in the state [64]. Additionally, dramatic job growth was seen in the increased number of workers from 950 to 2044 during 2007. In 2013, the average wage of this sector was USD 22,923, and which ranked 57th in the U.S. [65]. Additionally, the Indiana Business Research Center's [63] focus groups with local community leaders revealed that tourism provides economic growth to Orange County communities and there is still a room for further improvement. While positive economic growth is relatively easy to perceive by residents, the other impacts may be more subtle and difficult to determine. 


\subsection{Measurements and Instrument Design}

The study instrument is comprised of four sections: resident characteristics (sociodemographics), perceived tourism impacts, perceptions of TCQOL, and support for tourism. The perceived tourism impacts section records respondent perceptions of positive and negative impacts of tourism using a 5-point Likert scale ( 1 = strongly disagree to $5=$ strongly agree). The indicators for resident-perceived tourism impacts were adopted from the literature on tourism impacts $[8,32,53]$.

Conceptually, TCQOL represents resident perceptions of community QOL resulting from tourism development. The appraisal of community QOL should include satisfaction and importance perceived by individuals $[66,67]$. The TCQOL-measuring approach includes scales of importance, satisfaction, and perceived tourism effect ratings on TCQOL indicators $[12,68,69]$. The TCQOL score is therefore estimated in conjunction with QOL scores and the tourism effect. The equation for TCQOL scores is as follows: $\mathrm{TCQOL}=($ satisfaction $\times$ importance $) 1 / 2 \times$ (tourism effect) .

Residents who recognize high satisfaction and importance and increased effects of tourism perceive higher community QOL in the context of local tourism development and vice versa. The indicators of TCQOL comprise overall community livability, services, and conditions $[12,15,24]$. Respondents rated importance $(1=$ not at all important to $5=$ extremely important), satisfaction $(1=$ not at all satisfied to $5=$ extremely satisfied $)$, and perceived effects of tourism $(1=$ tourism greatly decreases to $5=$ tourism greatly increases) using three TCQOL indicators, and the TCQOL scores were calculated accordingly, ranging from 1 to 25 .

Regarding support for tourism development, the respondents were asked their support level for current/additional tourism development and satisfaction with current tourism development using a 5-point Likert scale ( 1 = strongly disagree to 5 = strongly agree).

\subsection{Data Collection and Analysis Methods}

The site for this study encompassed the communities in Orange County, Indiana. This data were collected during August and September 2011. This study used the structural equation modeling (SEM) approach for hypothesis testing because of proposed model incorporating latent and observed variables. The rule of thumb for the SEM approach sample size is that the number of cases should be 5-10 times that of the observed variables [70]. In total, 37 variables are related to the research hypotheses. Therefore, this research should require at least 370 respondents. To achieve this sample size, 3000 randomly selected households in the Orange County were used as the sampling frame and each household was sent a survey instrument by mail. The household address list was purchased from a marketing firm. There were 387 survey instruments returned for insufficient addresses, and 324 usable surveys instruments returned, for a response rate of $12.4 \%$. Compared with the response rate in other resident attitude studies, which have administered surveys by mail, the response rate of our surveys was low. For example, tourism development studies have reported response rates of 70\% [8], $52 \%$ [27], 19\% [71], and 14.6\% [53]. The low response rate is one of the limitations of the research, which may minimize the generalizability of the findings.

The data form the 324 questionnaires was entered into a Statistical Package for the Social Scientist (SPSS) 16 file, and then its credibility was verified. This process included identifying errors, missing data, and outliers [70,72]. The results of this survey revealed no out-of-range values and means, and the standard deviations were acceptable. The data in a few questionnaires was missing, and the percentage of missing data varied from variable to variable. The highest missing data rate was $4.0 \%$ of the total number of cases. A missing data rate lower than $5 \%$ has been suggested to indicate randomly missing data resulting in less severe problems [73]. Regarding outliers, the data set was examined for univariate outliers by verifying the $z$ scores. Some variables had outliers (absolute $z$ score $>3.29$ ). The ratio of outliers was low for all variables (0-2.8\%). The limited amount of outliers may thus not jeopardize data credibility. Considering data integrity, the authors retained the outliers.

The Analysis of Moment Structure (AMOS) 17.0 ver. software package was used for the SEM. Because the analytical framework of the present study encompasses observed measures and latent 
constructs, SEM is an appropriate approach to estimating the measurement model and relationships among latent constructs. A two-step approach was used to validate the measurement model and test the structural model $[74,75]$. For validating the measurement model, the latent constructs were tested for overall model fit, reliability, and validity using confirmatory factor analysis (CFA). The standardized loadings and composite reliability estimates of the observed variables were calculated for examining scale reliability and validity. The proposed hypotheses were tested. Several model fit indices, including chi-square $\left(\chi^{2}\right)$, normed fit index (NFI), non-normed fit index (NNFI), comparative fit index $(\mathrm{CFI})$, and root mean square error of approximation (RMSEA), were calculated, which helped estimate overall model goodness of fit. NFI, NNFI, and CFI values greater than 0.9 and an RMSEA value less than 0.06 are the criteria for acceptable fit $[70,76]$.

\section{Results and Discussion}

\subsection{Participant Profile}

As seen in Table 1, Respondent demographics, there were slightly more male participants $(56.8 \%)$ than female participants. Most of the respondents were 46-65 years old (50\%). The education distribution showed that $53.4 \%$ of the respondents had high-school degrees, $29.8 \%$ had a college diploma, and a small percentage of the respondents attended only grade school $(2.5 \%)$. The respondents were highly diverse in household income. The majority (28.3\%) reported an annual income in the range of 20,000-39,999, followed by less than 20,000 (18.9\%), 60,000-79,999 (18.2\%), 40,000-59,999 $(16.5 \%)$, over 100,000 (10.8\%), and 80,000-99,999 (7.4\%).

Table 1. Respondent demographics.

\begin{tabular}{lll}
\hline Variable & Category & Distribution (Valid Percentage) \\
\hline Gender & Female & $139(43.2)$ \\
& Male & $183(56.8)$ \\
\hline Age & $18-25$ & $7(2.2)$ \\
& $26-45$ & $55(17.2)$ \\
& $46-65$ & $160(50.0)$ \\
& Over 65 & $98(30.6)$ \\
\hline Education & Grade School & $8(2.5)$ \\
& High School & $172(53.4)$ \\
& College & $96(29.8)$ \\
& Graduate School & $46(14.3)$ \\
\hline \multirow{2}{*}{ Annual Household Income } & $>20,000$ & $56(18.9)$ \\
& $20,000-39,999$ & $84(28.3)$ \\
& $40,000-59,999$ & $49(16.5)$ \\
& $60,000-79,999$ & $54(18.2)$ \\
& $80,000-99,999$ & $22(7.4)$ \\
& Over 100,000 & $32(10.8)$ \\
\hline
\end{tabular}

\subsection{Descriptive Analysis}

Table 2 indicates the constructs and indicators of this study. The mean score of each indicator obtained on the basis of the descriptive statistical analysis (Table 2) indicates that from an economic perspective, overall, residents mostly agree that they and the community receives economic benefits from tourism. Respondents agree that tourism generates new income $(M=4.23)$, creates job opportunities $(\mathrm{M}=4.10)$ and investments $(\mathrm{M}=3.94)$, and provides other benefits to communities. However, they are somewhat undecided regarding the negative economic consequences of tourism.

Tourism yields positive and negative sociocultural consequences like many other economically oriented activities. Results (Table 2) indicate that residents perceived positive sociocultural consequences such are increased recreational opportunities $(\mathrm{M}=3.90)$ and availability of cultural, 
historical, and entertainment activities $(\mathrm{M}=3.81)$. Additionally, they agree that tourism improves service quality in restaurants, shops, and hotels $(M=3.73)$ and the service levels of police and firefighters $(M=3.30)$. Respondents indicate that tourism is not creating negative sociocultural impacts on the communities.

From an environmental perspective, the respondents tend to agree that tourism improves community appearance $(\mathrm{M}=3.98)$ and helps increase restoration of buildings and natural resources $(\mathrm{M}=3.81)$. They also perceive low levels of negative environmental consequences such as concern over traffic congestion because of tourism $(\mathrm{M}=3.34)$, various forms of pollution $(\mathrm{M}=2.76)$, deteriorating environment $(\mathrm{M}=2.42)$, and littering/solid waste problems $(\mathrm{M}=2.80)$.

Table 2. Descriptive analysis of tourism impacts and support for tourism.

\begin{tabular}{lcc}
\hline Constructs and Indicators & Mean & SD \\
\hline Positive economic impacts (PEC) & & \\
Economic contributor (PEC1) & 4.10 & 0.92 \\
Benefiting business (PEC2) & 4.18 & 0.835 \\
New income (PEC3) & 4.23 & 0.747 \\
Tax revenues (PEC4) & 4.09 & 0.846 \\
New jobs (PEC5) & 4.10 & 0.861 \\
More investment (PEC6) & 3.94 & 0.920 \\
Infrastructure improvement (P EC7) & 3.82 & 0.955 \\
\hline Negative economic impacts (NEC) & & \\
Inflation of goods and services (NEC1) & 3.30 & 1.024 \\
Pricy land and house (NEC2) & 3.50 & 1.029 \\
Increased tax (NEC3) & 3.07 & 0.942 \\
Increasing cost of living (NEC4) & 3.15 & 0.993 \\
\hline Positive sociocultural impacts (PSC) & & \\
Additional recreation opportunities (PSC1) & 3.90 & 0.909 \\
Improving quality of services (PSC2) & 3.73 & 0.876 \\
Better police and firefighting protection (PSC3) & 3.30 & 0.966 \\
More cultural, historical and entertainment activities (PSC4) & 3.81 & 0.873 \\
\hline Negative sociocultural impacts (NSC) & & \\
Disrupting quality of life (NSC1) & 2.27 \\
Overcrowded (NSC2) & 0.972 \\
Overused recreational resources (NSC3) & 2.12 & 0.950 \\
Tourism growing too fast (NSC4) & 2.07 & 0.802 \\
Crime and vandalism (NSC5) & 2.03 & 0.811 \\
\hline Positive environmental impacts (PEN) & 2.20 & 0.972 \\
Valued and protected nature diversity (PEN1) & & \\
Protecting wildlife and habitats (PEN2) & 3.39 & 0.844 \\
Sustainable natural environment (PEN3) & 3.10 & 0.893 \\
Promoting positive ethics (PEN4) & 3.18 & 0.854 \\
Harmony development of natural environment (PEN5) & 3.18 & 0.867 \\
Restoration of historical/cultural buildings and natural resources (PEN6) & 3.17 & 0.878 \\
Improving community appearance (PEN7) & 3.81 & 0.860 \\
\hline Negative environmental impacts (NEN) & 3.98 & 0.833 \\
Traffic congestion (NEN1) & & \\
Pollutions (NEN2) & 3.34 & 1.110 \\
Deteriorated environment quality (NEN3) & 2.76 & 0.930 \\
Littering and solid waste (NEN4) & 2.42 & 0.915 \\
Tourism support (TS) & 2.80 & 0.988 \\
Satisfied with current tourism development (TS1) & & \\
Support current tourism development (TS2) & 3.61 & 0.957 \\
Support additional tourism development (TS3) & 3.81 & 0.870 \\
\hline & 3.88 & 0.902 \\
\hline
\end{tabular}


Three indicators were used to measure the levels of resident support for tourism. Overall, the results show that the residents modestly support tourism development $(\mathrm{M}=3.81)$ and are satisfied with $(\mathrm{M}=3.61)$ current tourism development, and modestly support further tourism development $(\mathrm{M}=3.88)$.

Regarding TCQOL indicators, residents considered that overall community livability is associated with satisfaction $(M=3.49)$, high importance $(M=4.36)$, and slightly high tourism influence $(M=3.58)$. Overall community condition is the most important factor $(\mathrm{M}=4.38)$ that is most affected by tourism $(\mathrm{M}=3.65)$. See Table 3 .

Table 3. Means for TCQOL indicators.

\begin{tabular}{lcccc}
\hline & Satisfaction & Importance & Tourism Effect & TCQOL Score \\
\hline Overall community livability (TCQOL1) & 3.49 & 4.36 & 3.58 & 14.13 \\
Overall community conditions (TCQOL2) & 3.28 & 4.38 & 3.65 & 13.91 \\
Overall community services (TCQOL3) & 3.33 & 4.18 & 3.58 & 13.32 \\
\hline
\end{tabular}

\subsection{Scale Reliability and Validity}

The analytical framework comprises eight latent constructs; positive economic, sociocultural, and environmental impacts: negative economic, sociocultural, and environmental impacts; TCQOL; and support for tourism — which were measured on the basis of the underlying observed variables. To ensure consistency and accuracy in the measures on each construct, scale reliability and validity were assessed. CFA with the maximum-likelihood method was used to evaluate reliability and validity. A 37-indicator, eight-latent-construct model was thus estimated.

The CFA report revealed the goodness-of-fit indices of the measurement model to be as follows: $\chi^{2}(601)=1331.899(p=0.000), \mathrm{CFI}=0.91, \mathrm{NFI}=0.85, \mathrm{NNFI}=0.90$, and $\mathrm{RMSEA}=0.06$. The measurement model has an acceptable model fit. The reliability estimates of the indicators range from 0.264 to 0.907 (Table 4), with those of the eight indicators lower than the suggested level of 0.50 [77]. However, these low-reliability indicators were significant to the construction of the model. Considering the importance of these indicators in the instrument, no item was eliminated. For construct reliability, the Cronbach's alpha coefficients range from 0.82 to 0.93 , which exceeds the recommended level of 0.70 [78]. The composite reliability of all the constructs ranges from 0.82 to 0.95 , which exceeds the recommended minimum level of 0.60 [79]. Convergent validity was examined on the basis of average variance extracted (AVE). The AVEs of all the constructs are higher than 0.50 (Table 4); thus, convergent validity is satisfied $[77,79]$.

Table 4. The measurement model.

\begin{tabular}{cccccc}
\hline $\begin{array}{c}\text { Constructs and } \\
\text { Indicators }\end{array}$ & $\begin{array}{c}\text { Standardized } \\
\text { Loading }\end{array}$ & $\begin{array}{c}\text { Indicator } \\
\text { Reliability }\end{array}$ & $\begin{array}{c}\text { Composite } \\
\text { Reliability }\end{array}$ & $\begin{array}{c}\text { Cronbach's } \\
\text { Alpha }\end{array}$ & AVE \\
\hline PEC & & & 0.95 & 0.93 & 0.67 \\
PEC1 & $0.776^{*}$ & 0.603 & & & \\
PEC2 & $0.822^{*}$ & 0.675 & & \\
PEC3 & $0.887^{*}$ & 0.787 & & \\
PEC4 & $0.809 *$ & 0.655 & & \\
PEC5 & $0.832 *$ & 0.693 & & \\
PEC6 & $0.847^{*}$ & 0.718 & & \\
PEC7 & $0.762 *$ & 0.581 & & \\
\hline NEC & & & 0.82 & \\
NEC1 & $0.671 *$ & 0.450 & & \\
NEC2 & $0.514 *$ & 0.264 & & \\
NEC3 & $0.724 *$ & 0.524 & & \\
NEC4 & $0.969 *$ & 0.939 & & \\
\hline
\end{tabular}


Table 4. Cont.

\begin{tabular}{|c|c|c|c|c|c|}
\hline $\begin{array}{l}\text { Constructs and } \\
\text { Indicators }\end{array}$ & $\begin{array}{l}\text { Standardized } \\
\text { Loading }\end{array}$ & $\begin{array}{l}\text { Indicator } \\
\text { Reliability }\end{array}$ & $\begin{array}{l}\text { Composite } \\
\text { Reliability }\end{array}$ & $\begin{array}{c}\text { Cronbach's } \\
\text { Alpha }\end{array}$ & AVE \\
\hline PSC & & & 0.87 & 0.84 & 0.57 \\
\hline PSC1 & 0.787 * & 0.620 & & & \\
\hline PSC2 & 0.760 * & 0.578 & & & \\
\hline PSC3 & 0.719 * & 0.517 & & & \\
\hline PSC4 & 0.757 * & 0.573 & & & \\
\hline NSC & & & 0.92 & 0.90 & 0.66 \\
\hline NSC1 & 0.802 * & 0.643 & & & \\
\hline NSC2 & 0.832 * & 0.692 & & & \\
\hline NSC3 & 0.871 * & 0.758 & & & \\
\hline NSC4 & 0.870 * & 0.756 & & & \\
\hline NSC5 & 0.673 * & 0.453 & & & \\
\hline PEN & & & 0.93 & 0.91 & 0.60 \\
\hline PEN1 & 0.780 * & 0.609 & & & \\
\hline PEN2 & 0.877 * & 0.769 & & & \\
\hline PEN3 & 0.859 * & 0.738 & & & \\
\hline PEN4 & 0.877 * & 0.768 & & & \\
\hline PEN5 & 0.841 * & 0.707 & & & \\
\hline PEN6 & $0.546^{*}$ & 0.298 & & & \\
\hline PEN7 & 0.587 * & 0.344 & & & \\
\hline NEN & & & 0.84 & 0.83 & 0.58 \\
\hline NEN1 & 0.540 * & 0.292 & & & \\
\hline NEN2 & 0.812 * & 0.660 & & & \\
\hline NEN3 & 0.842 * & 0.708 & & & \\
\hline NEN4 & $0.814^{*}$ & 0.662 & & & \\
\hline TCQOL & & & 0.95 & 0.88 & 0.73 \\
\hline TCQOL1 & 0.952 * & 0.907 & & & \\
\hline TCQOL2 & 0.905 * & 0.820 & & & \\
\hline TCQ̄OL3 & 0.681 * & 0.464 & & & \\
\hline TS & & & 0.87 & 0.82 & 0.66 \\
\hline TS1 & $0.626^{*}$ & 0.392 & & & \\
\hline TS2 & 0.923 * & 0.746 & & & \\
\hline TS3 & 0.863 * & 0.851 & & & \\
\hline
\end{tabular}

Note: * indicates significance at the 0.001 level.

\subsection{Hypothesis Testing}

$\mathrm{H} 1, \mathrm{H} 2$, and $\mathrm{H} 3$ involved testing the structural models. The measurement model has been tested; thus, a structural model with eight latent constructs and 37 indicators can be evaluated. The goodness-of-fit indices for this study were $\chi^{2}(599)=1311.537(p=0.000), \mathrm{CFI}=0.92, \mathrm{NFI}=0.86$, NNFI $=0.90$, and RMSEA $=0.06$. The hypothesized structural model exhibited a good fit with empirical data. The results of the structural model testing are illustrated in Figure 2. Seven paths, PSC to TCQOL, PEN to TCQOL, TCQOL to TS, PEC to TS, PSC to TS, NSC to TS, and NEN to TS, are significant. 


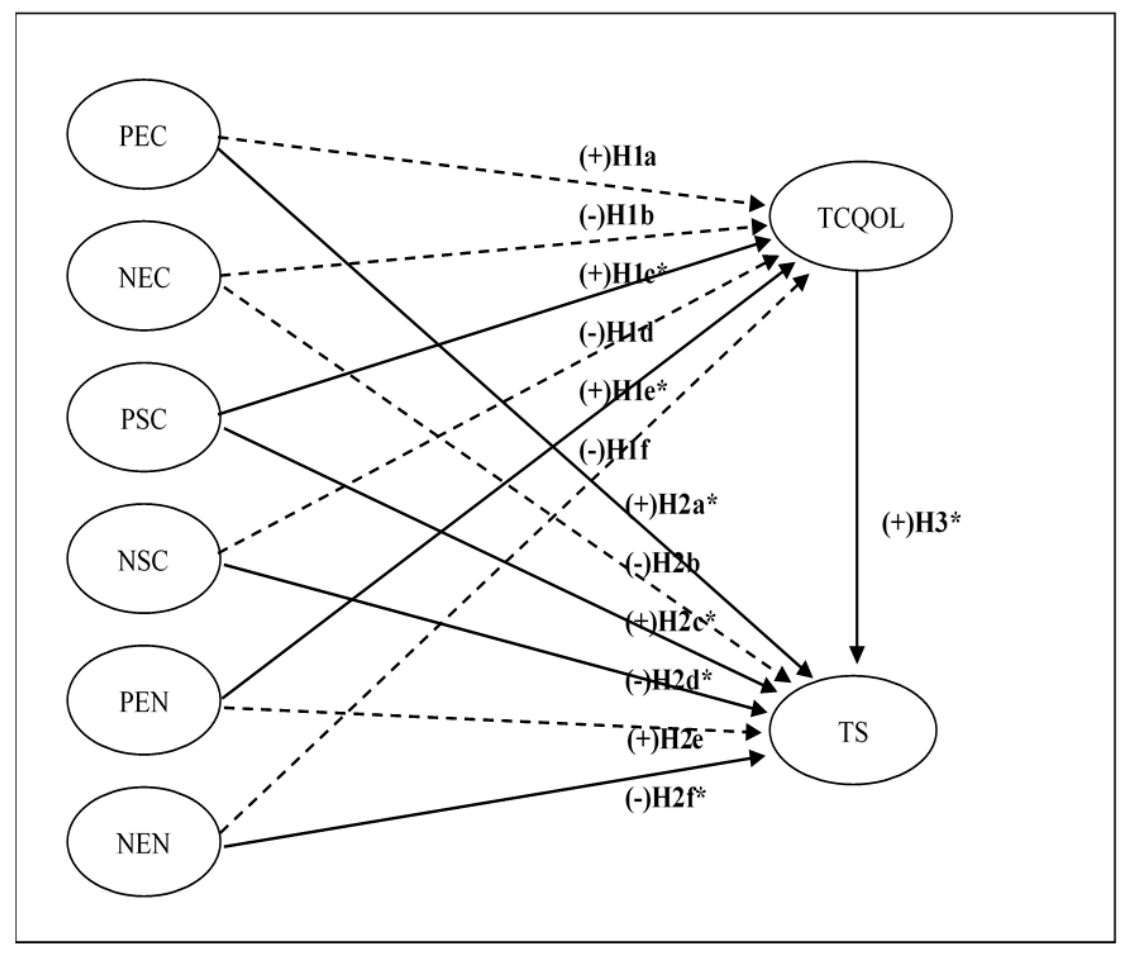

Figure 2. Proposed structural model and its results $\left({ }^{*}=\right.$ significance at the 0.05 level).

H1 assumed that resident-perceived tourism impacts in a particular dimension affect TCQOL. Two path hypotheses (H1c: Perceived positive sociocultural impacts positively affect TCQOL and H1e: Positive environmental impacts positively affect TCQOL are supported. Four path hypotheses (H1a, H1b, H1d, and H1f) are not supported. The findings show that two positive impacts, sociocultural and environmental impacts, contribute to TCQOL. However, resident community QOL resulting from tourism is not affected by positive economic impacts. This implies that because tourism development is reintroduced to Orange County, residents perceived low economic benefits from tourism sector and thus limited effects on community QOL. Another possibility is that residents are more concerned about the effects of positive sociocultural and environmental consequences rather than those of positive economic impacts on community QOL. The results did not support the concept that negative economic, sociocultural, and environmental consequences negatively affect resident community QOL. This finding is inconsistent with those of other empirical studies $[8,9]$. Tourism impact studies have concluded that positive impacts improve resident QOL and vice versa. However, this is not a universal rule in practice, as the tourism development stage and capacity to absorb tourism-induced impacts may change resident attitudes toward tourism $[48,54,80]$. The lack of significant negative relationships between negative impacts and TCQOL may thus be due to the stage of tourism development in Orange County. Specifically, tourism in Orange County is a re-emerging industry, which implies that the number of tourist attractions and tourists may be relatively low, thus typically causing less negative tourism impacts in this tourism development context. Another reason might be that residents may be euphoric because of the reintroduction of tourism development, and promise of economic benefits, so may have a higher tolerance toward negative consequences at this stage. This idea is in accordance with Doxey's model [81], which surmised that residents, such as those in this case, may be in the "euphoria" stage in terms of response to tourism.

$\mathrm{H} 2$ and $\mathrm{H} 3$ postulated that residents perceived tourism impacts in a particular dimension, and TCQOL affects support for tourism. Five of the seven hypothesized paths (H2a, H2c, H2d, H2f, and $\mathrm{H} 3)$ in the proposed model are statistically significant (Table 5). Two of the proposed hypotheses ( $\mathrm{H} 2 \mathrm{~b}$ and H2e) are not significant; however, their directions were predicted correctly. Therefore, perceived 
economic and sociocultural benefits and TCQOL have significant positive impacts on support for tourism. In addition, negative sociocultural and environmental consequences reversely affect support for tourism. Overall, the results are consistent with previous studies $[8,10,50,53,56,82]$. The insignificant relationship between negative economic impacts and support for tourism development may be explained by the fact that host communities place higher importance on economic gains than any other impacts $[34,50,83]$. Residents focus on economic gains; thus, they underestimate the potential economic costs of tourism, which in turn do not significantly affect support for tourism. Moreover, limited environmental improvement during early tourism development stage may have resulted in an insignificant relationship between environmental benefits and support for tourism development.

Table 5. Estimated standardized coefficients and results of hypothesis testing.

\begin{tabular}{ccccccc}
\hline & Paths & \multicolumn{1}{c}{ Standardized Regression Weight } & Sig. & Hypotheses & Results \\
\hline PEC & $\rightarrow$ & TCQOL & 0.135 & 0.194 & H1a & Rejected \\
NEC & $\rightarrow$ & TCQOL & 0.160 & 0.055 & H1b & Rejected \\
PSC & $\rightarrow$ & TCQOL & 0.334 & $0.009^{*}$ & H1c & Accepted \\
NSC & $\rightarrow$ & TCQOL & -0.104 & 0.231 & H1d & Rejected \\
PEN & $\rightarrow$ & TCQOL & 0.160 & $0.040^{*}$ & H1e & Accepted \\
NEN & $\rightarrow$ & TCQOL & -0.108 & 0.175 & H1f & Rejected \\
PEC & $\rightarrow$ & TS & 0.165 & $0.042^{*}$ & H2a & Accepted \\
NEC & $\rightarrow$ & TS & -0.076 & 0.223 & H2b & Rejected \\
PSC & $\rightarrow$ & TS & 0.322 & $0.003^{*}$ & H2c & Accepted \\
NSC & $\rightarrow$ & TS & -0.241 & $0.000^{*}$ & H2d & Accepted \\
PEN & $\rightarrow$ & TS & 0.038 & 0.549 & H2e & Rejected \\
NEN & $\rightarrow$ & TS & -0.129 & $0.050^{*}$ & H2f & Accepted \\
TCQOL & $\rightarrow$ & TS & 0.113 & $0.040^{*}$ & H3 & Accepted \\
\hline
\end{tabular}

Note: * indicates significance at the 0.05 level.

\section{Conclusions}

The section above discusses resident perceptions of tourism development and the results of hypotheses testing. The following section addresses the research questions.

\subsection{Research Question 1: Do Resident-Perceived Tourism Impacts Influence TCQOL?}

Yes they do, and this research question highlights the influences of a particular tourism impact on community QOL and was examined through H1a, H1b, H1c, H1d, H1e, and H1f. The findings indicate that perceived positive sociocultural impacts positively affect TCQOL (H1c), and positive environmental impacts positively affect TCQOL (H1e). The results suggest that tourism related sociocultural and environmental benefits significantly influence community QOL in Orange County. It has been argued that positive tourism impacts improve resident QOL, whereas negative tourism consequences degrade their living experiences. However, this may not always be the case in practice. According to this research, economic benefits and negative tourism impacts do not affect community QOL. A possible explanation for this phenomenon may be differences in the stage of tourism development across Orange County and/or a certain capacity to absorb tourism impacts.

\subsection{Research Question 2: Can Resident Perceptions of Tourism Impacts Predict Support for Tourism Development?}

Yes they can, and this question was examined through $\mathrm{H} 2 \mathrm{a}, \mathrm{H} 2 \mathrm{~b}, \mathrm{H} 2 \mathrm{c}, \mathrm{H} 2 \mathrm{~d}, \mathrm{H} 2 \mathrm{e}$, and $\mathrm{H} 2 \mathrm{f}$. The findings suggest that economic and sociocultural benefits positively influence resident support for tourism, whereas negative sociocultural and environmental consequences reduce their support. In general, the results are consistent with previous empirical studies. The insignificant relationship between negative economic impacts and support for tourism development may be explained by 
the importance that Orange County communities place on tourism. The insignificant relationship between environmental benefits and support for tourism development may be explained by limited to no environmental benefits of tourism development. From a theoretical perspective, the results support SET. In resident attitude studies, positive-negative economic, environmental, and sociocultural impacts have been identified in the exchange process. In the tourism literature, SET suggests that residents tend to have positive perceptions of tourism and subsequently support tourism development when perceived benefits outweigh the costs. Numerous studies have reported that SET explains how residents react to tourism development $[37,49,50,82]$.

\subsection{Research Question 3: Can TCQOL Predict Resident Support for Tourism?}

Yes, and furthermore TCQOL represents a useful concept in predicting resident support for tourism. The prevailing belief is that the positive and negative tourism impacts influence residents' support for tourism, and it is clear that community QOL plays an important factor to host community in terms of tourism support. The study findings demonstrate that resident perceptions of community QOL resulting from tourism can serve as a valuable concept for evaluating resident support for tourism, which further contributes to SET.

Residents' support for tourism is important to the development, and sustainability of tourism [84]. Responsible tourism planning seeks to optimize the host community's wellbeing and minimizing tourism development costs [85]. Instead of agribusiness, tourism is a re-emerging industry in host communities, and tourism practitioners should ensure benefits to the entire county that leads to local prosperity. Examining the relationships between TCQOL and its antecedents/consequences not only helps identify the crucial effects of tourism impacts on community QOL but also extends evaluations for support for tourism in a tourism destination. The results show that both sociocultural and environmental benefits contribute to host the community living experience. Economic and sociocultural benefits, negative sociocultural and environmental impacts, and TCQOL influence resident support for tourism development. These results indicate that resident perception of tourism impacts influence community QOL, and that tourism development impacts and community QOL affect support for tourism in Orange County, IN. The study model can be helpful in understanding the factors that influence resident community QOL and their support for tourism in a tourism destination, which contribute to the planning of strategic development programs for tourism destinations. Orange County tourism leaders and policy makers should make more efforts toward encouraging positive sociocultural effects such as (1) creating more recreation and entertainment opportunities that can also be used by locals; (2) improving public services; (3) educating tourists on best behavior practices, and; (4) publicize the positive effects of tourism beyond the obvious economic ones.

TCQOL evaluates residents' living experiences by incorporating satisfaction, importance, and tourism effect that highlight the subjective nature of lived experiences in the context of tourism development. This study examines the relationships among TCQOL, tourism impacts, and support for tourism. This approach helps researchers identify important factors that contribute to TCQOL and support for tourism from the residents' perspective. The major contribution of this study therefore is advancing knowledge by explaining which tourism impacts influence TCQOL, and how tourism impacts and TCQOL affect resident support for tourism. It is thus a valuable tool when considering both tourism scholars' and practitioners' successful development and management of existing and future tourism programs that can ensure resident QOL in the tourism development process. The proposed model can be used to investigate which tourism impacts affect resident perceptions of TCQOL and how tourism impacts and TCQOL influence resident support for tourism across different types/stages of tourism development. For example, resident perceptions of tourism impacts and TCQOL in Hawaii might differ from those in Las Vegas, and the pattern of the influence of perceived tourism impacts on resident community QOL may vary depending on the types/stages of tourism development. This research theme contributes not only to exploring tourism impacts and community QOL but also investigating the pattern of these relationships in a rural tourism destination. 
Quality tourism experiences link to the distribution of benefits and costs to both residents and tourists [86]. The host communities are considered as part of the tourism experiences, and the importance of their support has been well acknowledged [51,52]. Sustainable tourism development incorporates all stakeholders and highlights the importance of residents' quality of life. Barkley [87] argued the distribution of benefits and costs should equitably implement among individuals and groups. Galston and Baehler [88] indicated that defining acceptable development is equity and highlight growth strategies should be fairly impact on community. Thus impacts studies such as equity among interest groups (i.e., dependency of tourism) in a community, carrying capacity, limits of accept change, and objective and subjective indicators can be applied in the planning process.

Acknowledgments: This research was supported by the Dissertation Fellowship of Indiana University and Ministry of Science and Technology under research grant 105-2628-H-002-004-MY2.

Author Contributions: Chia-Pin Yu contributed to the study design, data acquisition, statistical analysis, and manuscript preparation. Shu Tian Cole and Charles Chancellor contributed to the study design and refined the paper.

Conflicts of Interest: The authors declare no conflict of interest.

\section{References}

1. Zhang, J.; Inbakaran, R.; Jackson, M. Understanding community attitudes towards tourism and hosteguest interaction in the urban-rural border region. Tour. Geogr. Int. J. Tour. Space Place Environ. 2006, 8, 182-204.

2. Gursoy, D.; Chi, C.G.; Dyer, P. Local's attitudes toward mass and alternative tourism: The case of Sunshine Coast, Australia. J. Travel Res. 2010, 49, 381-394. [CrossRef]

3. Murphy, P.E. Touirsm: A Community Approach; Methuen: New York, NY, USA, 1985.

4. Carmichael, B.A. Linking quality tourism experiences, residents' quality of life, and quality experiences for tourists. In Quality Tourism Experiences; Jennings, G., Nickerson, N.P., Eds.; Elsevier: Lodon, UK, 2006; pp. 115-135.

5. Murphy, P.E.; Pritchard, M.P.; Smith, B. The destination product and its impact on traveler perceptions. Tour. Manag. 2000, 21, 43-52. [CrossRef]

6. Andriotis, K. Community groups' perceptions of and preferences for tourism development: Evidence from Crete. J. Hosp. Tour. Res. 2005, 29, 67-90. [CrossRef]

7. Andereck, K.L.; Jurowski, C. Tourism and quality of life. In Quality Tourism Experiences; Jennings, G., Nickerson, N.P., Eds.; Elsevier: London, UK, 2006; pp. 136-154.

8. Ko, D.W.; Stewart, W.P. A structural equation model of residents' attitudes for tourism development. Tour. Manag. 2002, 23, 521-530. [CrossRef]

9. Roehl, W.S. Quality of life issues in a casino destination. J. Bus. Res. 1999, 44, 223-229. [CrossRef]

10. Vargas-Sanchez, A.; Plaza-Mejía, M.Á.; Porras-Bueno, N. Understanding residents' attitudes toward the development of industrial tourism in a former mining community. J. Travel Res. 2009, 47, 373-387. [CrossRef]

11. Kim, K.; Uysal, M.; Sirgy, J. How does tourism in a community impacts the quality of life of community ersidents? Tour. Manag. 2013, 36, 527-540. [CrossRef]

12. Andereck, K.L.; Nyaupane, G.P. Exploring the nature of tourism and quality of life perceptions among residents. J. Travel Res. 2011, 50, 248-260. [CrossRef]

13. Andereck, K.L.; Valentine, K.M.; Vogt, C.A.; Knopf, R.C. A cross-cultural analysis of tourism and quality of life perception. J. Sustain. Tour. 2007, 15, 483-502. [CrossRef]

14. Sirgy, M.J.; Meadow, H.L.; Samli, A.C. Past, persent and future: An overview of quality of life research in marketing. In New Dimensions in Marketing/Quality-of-Life Research; Sirgy, M.J., Samli, A.C., Eds.; Quorum Books: Westport, CT, USA, 1995; pp. 335-364.

15. Sirgy, M.J.; Rahtz, D.R.; Cicic, M.; Underwood, R. A method for assessing residents' satisfaction with community-based services: A quality-of-life perspective. Soc. Indic. Res. 2000, 49, 279-316. [CrossRef]

16. Liu, B. Quality of Life Indicators in U.S. Metropolitan Areas; Praeger: New York, NY, USA, 1976.

17. Lieske, J. The correlates of life quality in U.S. Metropolitan areas. J. Fed. 1990, 20, 43-54. [CrossRef]

18. Diener, E. Subjective well-being. Psychol. Bull. 1984, 95, 542-575. [CrossRef] [PubMed]

19. Veenhoven, R. Is happiness relative? Soc. Indic. Res. 1991, 24, 1-34. [CrossRef] 
20. Phillips, D. Quality of Life: Concept, Policy and Practice; Routledge: New York, NY, USA, 2006.

21. Andrew, F.M.; Withey, S.B. Social Indicators of Well Being: America's Perception of Life Quality; Plenum Press: New York, NY, USA, 1976.

22. Campbell, A.; Converse, P.E.; Rodgers, W.L. The Quality of American Life: Perspectives, Evaluations, and Aatisfactions; Russell Sage Foundation: New York, NY, USA, 1976.

23. Shin, D.C. Subjective indicators and the comparative evaluation of the quality of community life. Am. J. Commun. Psychol. 1980, 8, 523-535. [CrossRef]

24. Sirgy, M.J.; Cornwell, T. Further validation of the Sirgy et al.'s measure of community quality of life. Soc. Indic. Res. 2001, 56, 125-143. [CrossRef]

25. Grzeskowiak, S.; Sirgy, M.J.; Widgery, R. Residents' satisfaction with community services: Predictors and outcomes. J. Reg. Anal. Policy 2003, 33, 1-36.

26. Andereck, K.L. Environmental consequences of tourism: A review of recent research. In Linking Tourism, the Environment, and Sustainability; Annual Meeting of the National Recreation and Park Association, 1994; General Technical Report No. INT-GTR-323; CABI: Wallingford, UK, 1994; pp. 77-81.

27. Ap, J.; Crompton, J.L. Developing and testing a tourism impact scale. J. Travel Res. 1998, 37, $120-130$. [CrossRef]

28. Belisle, F.J.; Hoy, D.R. The perceived impact of tourism by residents a case study in Santa Marta, Colombia. Ann. Tour. Res. 1980, 7, 83-101. [CrossRef]

29. Brunt, P.; Courtney, P. Host perceptions of sociocultural impacts. Ann. Tour. Res. 1999, 26, 493-515. [CrossRef]

30. Keogh, B. Social impacts. In Outdoor Recreation in Canada; Wall, G., Ed.; John Wiley and Sons: Toronto, ON, Canada, 1989; pp. 223-275.

31. Lankford, S.V.; Howard, D.R. Developing a tourism impact attitude scale. Ann. Tour. Res. 1994, 21, 121-139. [CrossRef]

32. Liu, J.C.; Var, T. Resident attitudes toward tourism impacts in Hawaii. Ann. Tour. Res. 1986, 13, $193-214$. [CrossRef]

33. Liu, J.C.; Sheldon, P.J.; Var, T. Resident perception of the environmental impacts of tourism. Ann. Tour. Res. 1987, 14, 17-37. [CrossRef]

34. Akis, S.; Peristianis, N.; Warner, J. Residents' attitudes to tourism development: The case of Cyprus. Tour. Manag. 1996, 17, 481-494. [CrossRef]

35. Andriotis, K.; Vaughan, R.D. Urban residents' attitudes toward tourism development: The case of Crete. J. Travel Res. 2003, 42, 172-185. [CrossRef]

36. Marcouiller, D.W. Toward integrative tourism planning in rural America. J. Plan. Lit. 1997, 11, 337-357. [CrossRef]

37. Perdue, R.R.; Long, P.T.; Allen, L.R. Resident support for tourism development. Ann. Tour. Res. 1990, 17, 586-599. [CrossRef]

38. Tosun, C. Host perceptions of impacts: A comparative tourism study. Ann. Tour. Res. 2002, 29, $231-253$. [CrossRef]

39. Wan, P.Y.K. Governance of tourism planning in Macao. Tour. Anal. 2012, 17, 357-369. [CrossRef]

40. Presenza, A.; Del Chiappa, G.; Sheehan, L. Residents' engagement and local tourism governance in maturing beach destination. Evidence from an Italian case study. J. Destin. Mark. Manag. 2013, 2, 22-30. [CrossRef]

41. Sinclair-Maragh, G.; Gursoy, D.; Vieregge, M. Residents' perceptions toward tourism development: A factor-cluster approach. J. Destin. Mark. Manag. 2015, 4, 36-45.

42. McCool, S.F.; Martin, S.R. Community attachment and attitudes toward tourism development. J. Travel Res. 1994, 32, 29-34. [CrossRef]

43. Haralambopoulos, N.; Pizam, A. Perceived impacts of tourism: The case of Samos. Ann. Tour. Res. 1996, 23, 503-526. [CrossRef]

44. Harrill, R. Residents' attitudes toward tourism development: A literature review with implications for tourism planning. J. Plan. Lit. 2004, 18, 251-266. [CrossRef]

45. Weaver, D.B.; Lawton, L.J. Resident rerceptions in the urban-rural fringe. Ann. Tour. Res. 2001, 28, 439-458. [CrossRef]

46. Lindberg, K.; Johnson, R.L. Modeling resident attitudes toward tourism. Ann. Tour. Res. 1997, $24,402-424$. [CrossRef] 
47. Uysal, M.; Woo, E.; Singal, M. The Tourist Area Life Cycle (TALC) and its effect on the Quality- of-Life (QOL) of destination community. In Handbook of Tourism and Quality-of-Life Research; Uysal, M., Perdue, R., Sirgy, J., Eds.; Spring: Berlin, Germany, 2012; pp. 423-443.

48. Allen, L.R.; Long, P.T.; Perdue, R.R.; Kieselbach, S. The impact of tourism development on residents' perceptions of community life. J. Travel Res. 1988, 27, 16-21. [CrossRef]

49. Gursoy, D.; Jurowski, C.; Uysal, M. Resident attitudes: A Structural Modeling Approach. Ann. Tour. Res. 2002, 29, 79-105. [CrossRef]

50. Gursoy, D.; Rutherford, D.G. Host attitudes toward tourism: An improved structural model. Ann. Tour. Res. 2004, 31, 495-516. [CrossRef]

51. Andereck, K.L.; Vogt, C.A. The relationship between residents' attitudes toward tourism and tourism development options. J. Travel Res. 2000, 39, 27-36. [CrossRef]

52. Ap, J. Residents' perceptions on tourism impacts. Ann. Tour. Res. 1992, 19, 665-690. [CrossRef]

53. Dyer, P.; Gursoy, D.; Sharma, B.; Carter, J. Structural modeling of resident perceptions of tourism and associated development on the Sunshine Coast, Australia. Tour. Manag. 2007, 28, 409-422. [CrossRef]

54. Getz, D. Residents' attitudes towards tourism: A longitudinal study in Spey Valley, Scotland. Tour. Manag. 1994, 15, 247-258. [CrossRef]

55. Jurowski, C.; Gursoy, D. Distance effects on residents' attitudes toward tourism. Ann. Tour. Res. 2004, 31, 296-312. [CrossRef]

56. McGehee, N.G.; Andereck, K.L. Factors predicting rural residents' support of tourism. J. Travel Res. 2004, 43, 131-140. [CrossRef]

57. Stylidis, D.; Biran, A.; Sit, J.; Szivas, E.M. Residents' support for tourism development: The role of residents' place image and perceived tourism impacts. Tour. Manag. 2014, 45, 260-274. [CrossRef]

58. Skidmore, W. Theoretical Thinking in Sociology; Cambridge University Press: New York, NY, USA; London, UK, 1975.

59. Nunkoo, R.; Ramkissoon, H. Small island urban tourism: A residents' perspective. Curr. Issues Tour. 2010, 13, 37-60. [CrossRef]

60. Nunkoo, R.; Ramkissoon, H. Modeling community support for a proposed integrated resort project. J. Sustain. Tour. 2010, 18, 257-277. [CrossRef]

61. Nunkoo, R.; Ramkissoon, H. Residents' satisfaction with community attributes and support for tourism. J. Hosp. Tour. Res. 2011, 35, 171-190. [CrossRef]

62. Nunkoo, R.; Ramkissoon, H. Developing a Community Support Model for Tourism. Ann. Tour. Res. 2011, 38 , 964-988. [CrossRef]

63. Indiana Business Research Center \& Strategic Development Group. Benchmarking \& Target Industry Analysis Spotlight on a Changing Region. Available online: http://www.ibrc.indiana.edu/studies/ OrangeCountyBenchmarkStudy2011.pdf (accessed on 15 October 2010).

64. STATS Indiana. STATS Indiana Profile. Available online: http://www.stats.indiana.edu/uspr/a/us_profile_ frame.html (accessed on 4 October 2010).

65. STATAMERICA. USA Counties in Profile. Available online: http://www.statsamerica.org/USCP/ (accessed on 4 April 2016).

66. Brown, I.; Raphael, D.; Renwick, R. Quality of Life Profile, 2. Quality of Life Research Unit; Center for Health Promotion: Toronto, ON, Canada, 1998.

67. Felce, D.; Perry, J. Quality of life: Its definition and measurement. Res. Dev. Disabil. 1995, 16, 51-74. [CrossRef]

68. Massam, B.H. Quality of life: Public planning and private living. Prog. Plan. 2002, 58, 141-227. [CrossRef]

69. Yu, C.-P.; Cole, S.T.; Chancellor, C. Assessing community quality of life in the context of tourism development. Appl. Res. Qual. Life 2016, 11, 147-162. [CrossRef]

70. Hair, J.F.; Anderson, R.E.; Tatham, R.L.; Black, W.C. Multivariate Data Analysis with Readings; Prentice-Hall International: London, UK, 1998.

71. Chen, J.S. An investigation of urban residents' loyalty to tourism. J. Hosp. Tour. Res. 2000, 24, 5-19. [CrossRef]

72. Malhotra, N.K. Marketing Research: An Applied Orientation; Prentice Hall: Upper Saddle River, NJ, USA, 1999.

73. Tabachnick, B.G.; Fidell, L.S. Using Multivariate Statistics, 4; Allyn and Bacon: London, UK, 2001.

74. Anderson, J.C.; Gerbing, D.W. Structural equation modeling in practice: A review and recommended two-step approach. Psychol. Bull. 1988, 103, 411-423. [CrossRef] 
75. Byrne, B.M. Structural Equation Modeling with AMOS: Basic Concepts, Applications, and Programming; Routledge: New York, NY, USA, 2009.

76. Hu, L.; Bentler, P.M. Evaluation model fit. In Structural Equation Modeling: Concepts, Issues and Application; Hoyle, R.H., Ed.; SAGE Publications: Thousand Oak, CA, USA, 1995; pp. 76-99.

77. Fornell, C.; Larcker, D.F. Evaluating structural equation models with unobservable variables and measurement error. J. Mark. Res. 1981, 18, 39-50. [CrossRef]

78. Nunnally, J.C.; Bernstein, I.H. Psychometric Theory, 3rd ed.; McGraw-Hill: New York, NY, USA, 1994.

79. Bagozzi, R.P.; Yi, Y. On the evaluation of structure equation models. J. Acad. Mark. Sci. 1988, 16, 74-94. [CrossRef]

80. Butler, R.W. The concept of a tourist area cycle of evolution: Implications for management of resources. Can. Geogr. 1980, 24, 5-12. [CrossRef]

81. Doxey, G.V. A causation theory of visitor-resident irritants' methodology and research inferences. In Proceedings of the Sixth Annual Conference of the Travel Research Association, San Diego, CA, USA, 8-11 September 1975.

82. Yoon, Y.; Gursoy, D.; Chen, J.S. Validating a tourism development theory with structural equation modeling. Tour. Manag. 2001, 22, 363-372. [CrossRef]

83. Husbands, W. Social status and perception of tourism in Zambia. Ann. Tour. Res. 1989, 16, $237-253$. [CrossRef]

84. Jurowski, C. The interplay of elements affecting host community resident attitudes toward tourism: A path analytic approach. In Doctoral Dissertation; Virginia Tech University: Blacksburg, VA, USA, 1994.

85. Sharpley, R. Host perceptions of tourism: A review of the research. Tour. Manag. 2014, 42, 37-49. [CrossRef]

86. Jurowski, C.; Daniels, M.J.; Pennington-Gray, L. The distribution of tourism benefits. In Quality Tourism Experiences; Jennings, G., Nickerson, N.P., Eds.; Elsevier: Lodon, UK, 2006; pp. 192-207.

87. Barkley, D.L. Job Generation Strategies for Small Towns: An Overview of Problems and Potentials; Regional Economic Development Research Laboratory: Clemson, SC, USA, 1991.

88. Galston, W.A.; Baehler, K.J. Rural Development in the United States: Connecting Theory, Practice, and Possibilities; Island Press: Wachington, DC, USA, 1995.

(C) 2018 by the authors. Licensee MDPI, Basel, Switzerland. This article is an open access article distributed under the terms and conditions of the Creative Commons Attribution (CC BY) license (http:/ / creativecommons.org/licenses/by/4.0/). 